\title{
A Física nas Universidades Portuguesas
}

\author{
José Ferreira Gomes ${ }^{1}$, Elisabeth S. Vieira
}

A avaliação comparativa da produção científica das instituições portuguesas em determinada disciplina pode ser feita recorrendo às grandes bases de dados de referência que são hoje usadas em investigação científica. A mais conhecida é a Web of Science (WoS) da Thomson Reuters [1] que foi desenvolvida ao longo da segunda metade do Séc. XX nos Estados Unidos. Em 2004, a Elsevier B.V apresentou a Scopus [2] com a aspiração de oferecer uma alternativa, o que parece ter já conseguido. Na WoS é feita a classificação das revistas a um nível bastante específico constituído por mais de 250 categorias e, a um nível superior, em 22 áreas de conhecimento. A pesquisa pelas mais de 250 categorias é possível através do WoS [3], enquanto que a pesquisa pelas 22 áreas de conhecimento apenas é possível no Essential Science Indicators [4] (recurso adicional disponibilizado no portal da WoS e que se refere apenas às publicações, investigadores, instituições, países e revistas mais citadas). A Scopus apresenta a classificação das revistas num primeiro nível bastante específico em 295 catego- rias, a um nível intermédio constituído por 27 áreas de conhecimento e a um nível superior em 4 grandes áreas. $A$ pesquisa na Scopus pelos diferentes níveis de classificação das revistas apenas é possível para o nível intermédio e para o nível superior.

Para compararmos a produção científica das instituições portuguesas é mais cómodo o uso da Scopus, mas há indicações na literatura de que se podem obter resultados similares na WoS embora a classificação das revistas científicas não coincida. Na Figura 1 é apresentado o número de documentos originados por cada uma das universidades membros do CRUP em percentagem do total de documentos classificados na área da Física \& Astronomia para Portugal nos dois últimos quinquénios, 1998-2002 e 2003-07. O levantamento da produção científica foi efectuado associando a cada universidade todos os documentos onde pelo menos um dos endereços indicados pelos autores contém uma referência clara a essa instituição, a uma das suas unidades orgânicas ou dos seus grupos de investigação [5]. quinquénio anterior. A Universidade de Aveiro com 834 documentos ocupa a segunda posição, ultrapassando neste quinquénio as Universidades de Lisboa e de Coimbra. Para o último quinquénio verifica-se um aumento superior a $60 \%$ do número de documentos referenciados no Scopus para Portugal na área da Física \& Astronomia em relação ao quinquénio anterior. Estes resultados são discutidos em mais detalhe na Nota Técnica Research Metrics n ${ }^{\circ} 7$, "A especialização das universidades portuguesas - produção por área científica"[6].

Para além destes aspectos quantitativos, interessa também conhecer o impacto relativo das publicações originadas em cada uma das universidades. Para isso calculamos o número médio de citações de cada publicação com um endereço português dentro da área aqui considerada. Repete-se este cálculo para cada universidade e apresenta-se o rácio do impacto médio das publicações de cada universidade para o impacto médio nacional. A este indicador chamamos impacto relativo ao país.

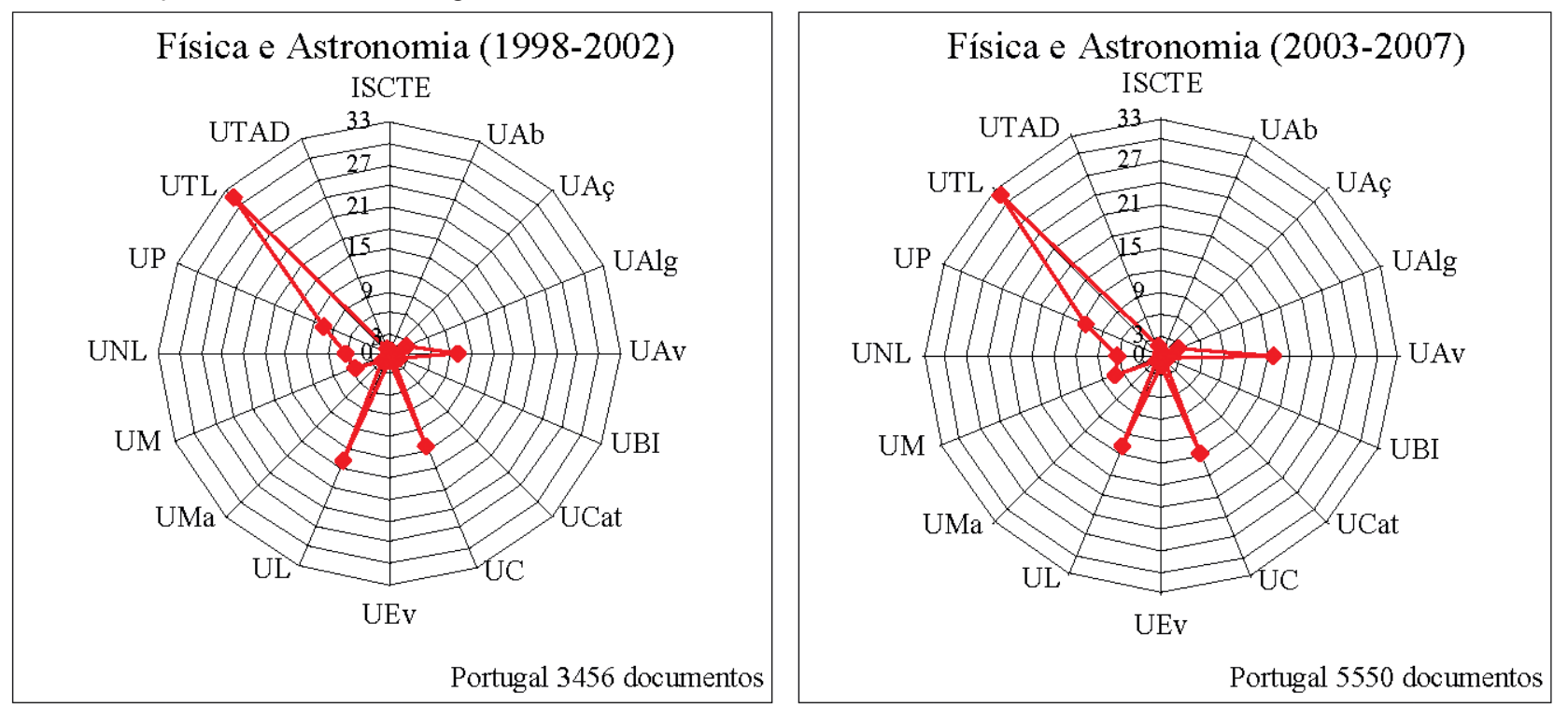

Figura 1 Percentagem de documentos da área de Física \& Astronomia originados pelas universidades membros do CRUP em relação ao número total de documentos com um endereço português nos quinquénios 1998-2002 e 2003-07

Centro de Química da Universidade do Porto, Requimte, Laboratório Associado para a Química Verde, Rua

do Campo Alegre, 687, 4169-007 Porto
Com 1677 documentos em 2003-07, a Universidade Técnica de Lisboa tem uma posição muito destacada, confirmando a posição já assumida no
O impacto relativo e a especialização de cada uma das universidades para a área da Física nos quinquénios 1998-2002 e 2003-07 são representados 
nas Figuras 2 e 3. A área dos círculos representa o número de documentos originados por cada uma das universidades, sendo a especialização definida pelo rácio entre o número de documentos classificados na área de Física \& Astronomia e o número total de documentos dessa instituição no mesmo período. Esta mesma especialização calculada para o país é representada por uma linha vertical.

Os resultados apresentados nas Figuras 2 e 3 demonstram que o grau de especialização relativa ao país sofreu um decréscimo no último quinquénio.

O mesmo pode ser verificado para a maioria das universidades, registando-se um aumento do valor da especialização apenas para o ISCTE, Universidade Aberta, Universidade Católica, Universidade Técnica de Lisboa e UTAD $(9 \%, 15 \%, 6 \%, 28 \%$ e $9 \%$, respectivamente).

As Universidade dos Açores e do Algarve apresentam os impactos mais elevados, (mas o pequeno número de documentos pode ser relevante na formação desta média), 1,97 e 1,61 respectivamente, destacando-se significativamente das restantes universidades.

Considerando apenas as universidades de maiores dimensões verifica-se que a Técnica de Lisboa, a Nova de Lisboa e a de Lisboa apresentam valores de impacto superiores à média nacional, 1,$21 ; 1,16$ e 1,08, respectivamente. Neste conjunto a Universidade Técnica de Lisboa é a que se encontra numa posição cimeira com valores de especialização e impacto relativo mais elevado $(28 \%$ e 1,21$)$.

Para compreender qual é a nossa posição na paisagem internacional, foi efectuado o mesmo estudo para a UE-15 e para alguns países individualmente, estando os resultados na Figura 4.

A área dos círculos representa o número de documentos referenciados na Scopus para cada país por milhão de habitantes [7], sendo agora usado o impacto relativo à média da UE-15 e a especialização deste agregado de
15 países é representada pela linha vertical. Relativamente ao número de documentos por milhão de habitantes, a Suécia apresenta o valor mais elevado enquanto Portugal, com a Grécia e a Espanha, apresentam os valores mais baixos $(65,72$ e 76 documentos/milhão de habitantes, respectivamente).

Os restantes países apresentam valores superiores ao conjunto UE-15 (92 documentos/milhão de habitantes).

Quanto à especialização, Portugal é um dos que apresenta valores de especialização mais elevada (15\%) sendo superado apenas pela França e Itália (18\% e $16 \%$ respectivamente).

O impacto das publicações portuguesas $(0,81)$ é ligeiramente inferior à média, tal como a Grécia, a Irlanda, a Espanha e a Itália $(0,70,0,83,0,92$ e 0,93 , respectivamente).

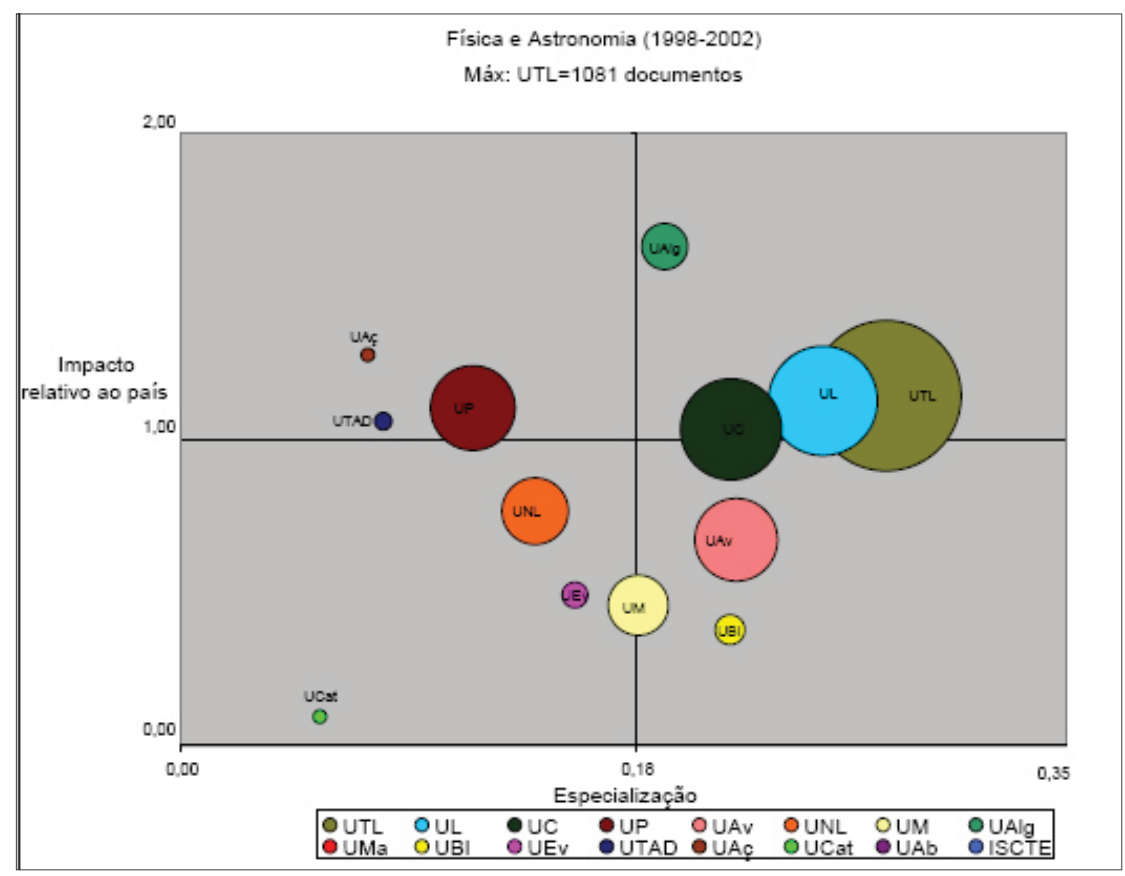

Figura 2 Impacto das universidades membro do CRUP relativamente ao país e especialização das mesmas na área da Física \& Astronomia no quinquénio 1998-2002

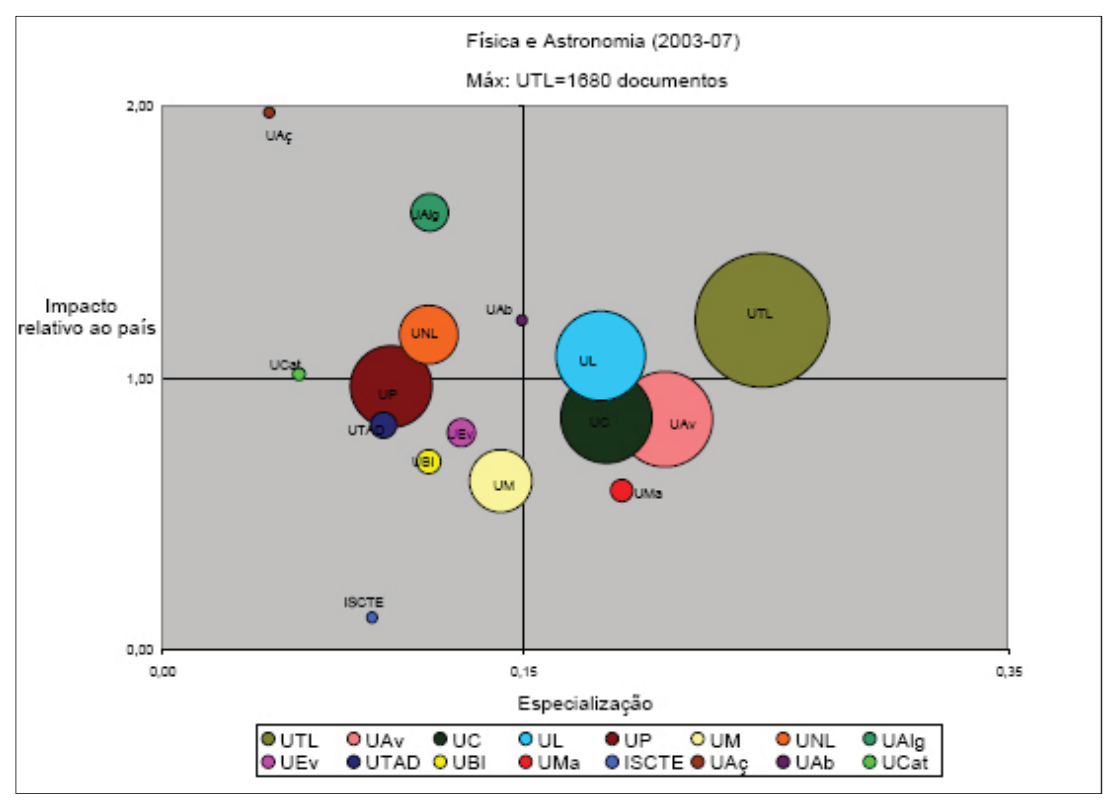

Figura 3 Impacto das universidades membro do CRUP relativamente ao país e especialização das mesmas na área de Física \& Astronomia no quinquénio 2003-07 


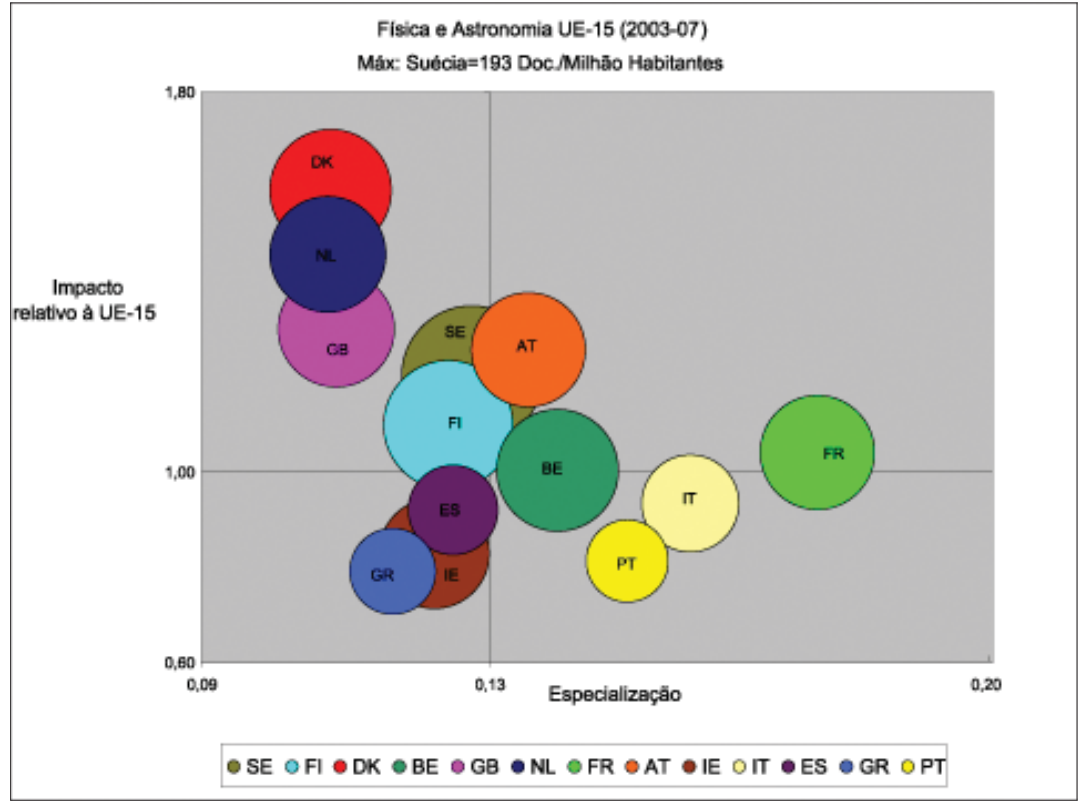

Figura 4 Impacto de alguns países pertencentes à UE-15 relativamente à média da UE-15 e sua especialização na área de Física \& Astronomia no quinquénio 2003-07

Comparando Portugal com a UE-15 e com alguns países pertencentes a este conjunto para as 26 áreas definidas pela Scopus (a área Multidisciplinar foi excluída neste ponto), verifica-se que a área predominante em Portugal é a
Engenharia com um maior número de documentos originados no quinquénio 2003 e 2007 por milhão de habitantes (75 documentos/milhão de habitantes) ao passo que no conjunto UE-15 esta área ocupa o terceiro lugar sendo os primeiros lugares ocupados pela $\mathrm{Me}$ dicine e pela Biochemistry, Genetics and Molecular Biology. Verifica-se na Tabela 1 que as áreas da Medicine, Neuroscience, Energy, Business, Managment and Accounting, Veterinary, Nursing, Arts and Humanities e Dentistry são aquelas que apresentam um número de documentos por milhão de habitantes bastante inferior à UE-15 estando todos os valores abaixo dos $50 \%$ dos relativos à UE-15. Para as áreas como Materials Science e Chemical Engineering, Portugal tem uma produtividade superior à da UE-15. Para a Agricultural and Biological Sciences, Chemistry e Environmental Science os valores encontram-se muito próximos dos obtidos para o agregado UE-15.

Tabela 1 Número de documentos por milhão de habitantes (representado na tabela pela coluna Prod.) classificados em cada uma das áreas definidas pela Scopus para Portugal, UE-15 e alguns membros da UE-15 no quinquénio 2003-07

\begin{tabular}{|c|c|c|c|c|c|c|c|c|c|c|c|}
\hline \multicolumn{3}{|c|}{ Portugal } & \multicolumn{2}{|c|}{ UE-15 } & \multirow{2}{*}{$\begin{array}{c}\text { Espanha } \\
\text { Prod. }\end{array}$} & \multirow{2}{*}{$\frac{\text { França }}{\text { Prod. }}$} & \multirow{2}{*}{$\frac{\text { Itália }}{\text { Prod. }}$} & \multirow{2}{*}{$\frac{\text { Holanda }}{\text { Prod. }}$} & \multirow{2}{*}{$\begin{array}{l}\text { Reino } \\
\text { Unido } \\
\text { Prod. }\end{array}$} & \multirow{2}{*}{$\frac{\text { Irlanda }}{\text { Prod. }}$} & \multirow{2}{*}{$\frac{\text { Grécia }}{\text { Prod. }}$} \\
\hline Ordem & Subcategorias & Prod. & Ordem & Prod. & & & & & & & \\
\hline 1 & Engineering & 75 & 3 & 95 & 71 & 102 & 84 & 147 & 142 & 156 & 105 \\
\hline 2 & Medicine & 70 & 1 & 228 & 186 & 192 & 190 & 425 & 402 & 282 & 213 \\
\hline 3 & $\begin{array}{l}\text { Biochemistry, Genetics and Molecular } \\
\text { Biology }\end{array}$ & 70 & 2 & 114 & 99 & 114 & 104 & 191 & 177 & 149 & 86 \\
\hline 4 & Physics and Astronomy & 65 & 4 & 92 & 76 & 123 & 92 & 122 & 118 & 116 & 72 \\
\hline 5 & Agricultural and Biological Sciences & 53 & 6 & 55 & 67 & 53 & 39 & 91 & 87 & 97 & 46 \\
\hline 6 & Chemistry & 52 & 7 & 55 & 68 & 64 & 47 & 62 & 66 & 63 & 41 \\
\hline 7 & Materials Science & 51 & 9 & 46 & 40 & 59 & 32 & 53 & 56 & 51 & 39 \\
\hline 8 & Computer Science & 40 & 5 & 45 & 45 & 47 & 39 & 67 & 63 & 82 & 66 \\
\hline 9 & Mathematics & 37 & 8 & 41 & 46 & 51 & 39 & 52 & 49 & 58 & 45 \\
\hline 10 & Environmental Science & 29 & 12 & 32 & 31 & 26 & 20 & 63 & 54 & 38 & 32 \\
\hline 11 & Chemical Engineering & 27 & 16 & 22 & 22 & 25 & 15 & 34 & 27 & 24 & 21 \\
\hline 12 & Earth and Planetary Sciences & 23 & 10 & 36 & 30 & 47 & 36 & 69 & 61 & 43 & 29 \\
\hline 13 & Immunology and Microbiology & 20 & 13 & 34 & 31 & 36 & 25 & 70 & 59 & 56 & 24 \\
\hline 14 & $\begin{array}{l}\text { Pharmacology, Toxicology and } \\
\text { Pharmaceutics }\end{array}$ & 14 & 15 & 27 & 26 & 23 & 25 & 46 & 44 & 29 & 20 \\
\hline 15 & Social Sciences & 12 & 11 & 29 & 14 & 16 & 10 & 61 & 88 & 50 & 21 \\
\hline 16 & Neuroscience & 10 & 14 & 29 & 19 & 26 & 27 & 59 & 55 & 34 & 14 \\
\hline 17 & Energy & 8 & 19 & 9 & 7 & 9 & 7 & 14 & 13 & 9 & 11 \\
\hline 18 & Economics, Econometrics and Finance & 5 & 22 & 8 & 7 & 6 & 5 & 21 & 20 & 14 & 7 \\
\hline 19 & Decision Sciences & 5 & 24 & 5 & 5 & 5 & 3 & 10 & 8 & 6 & 8 \\
\hline 20 & Psychology & 5 & 17 & 17 & 10 & 10 & 8 & 48 & 39 & 24 & 8 \\
\hline 21 & $\begin{array}{l}\text { Business, Management and } \\
\text { Accounting }\end{array}$ & 4 & 21 & 8 & 5 & 4 & 3 & 19 & 23 & 13 & 7 \\
\hline 22 & Health Professions & 4 & 18 & 13 & 5 & 10 & 8 & 27 & 22 & 16 & 12 \\
\hline 23 & Veterinary & 3 & 23 & 8 & 6 & 7 & 5 & 15 & 17 & 21 & 4 \\
\hline 24 & Nursing & 1 & 20 & 8 & 5 & 5 & 3 & 13 & 25 & 17 & 4 \\
\hline 25 & Arts and Humanities & 1 & 26 & 4 & 2 & 3 & 1 & 7 & 10 & 4 & 2 \\
\hline 26 & Dentistry & 1 & 25 & 4 & 3 & 1 & 3 & 8 & 7 & 6 & 5 \\
\hline & Todas áreas & 444 & --- & 731 & 628 & 731 & 602 & 1215 & 1203 & 987 & 629 \\
\hline
\end{tabular}




\section{REFERÊNCIAS}

[1] Thomson Reuters, http://www.thomsonreuters.com/

[2] Scopus, www.scopus.com/

[3] ISI Web of Knowledge, http://apps.isiknowledge.com/WOS_ GeneralSearch_input.do?highlighted_ tab=WOS\&product=WOS\&last_prod=
WOS\&SID=U1Jn3Adoln5P8PJ47Cf\&s earch_mode=GeneralSearch

[4] ISI Web of Knowledge, http://esi.isiknowledge.com/home.cgi

[5] H. Nouws, J. T. Albergaria, E. S. Vieira, C. Delerue-Matos, J. A. N. F. Gomes, "Documentos Indexados no ISI, Web of Knowledge, 2000-2007", Nota Técnica Research Metrics $n^{\circ}$ 1, 14.Jan.2008, em http://www.requimte.pt/metrics
[6] E.S. Vieira, H. Nouws, J. T. Albergaria, C. Delerue-Matos, J. A. N. F. Gomes, Nota Técnica Research Metrics $n^{\circ} 7$ em http://www.fc.up.pt/pessoas/jfgomes ou http://www.requimte.pt/researchmetrics

[7] Organisation for Economic Co-operation and Development, OECD, http://stats. oecd.org, consultado em Novembro de 2008.

\section{Curiosidades Científicas}

\section{A Química da Felicidade SUPREMA}

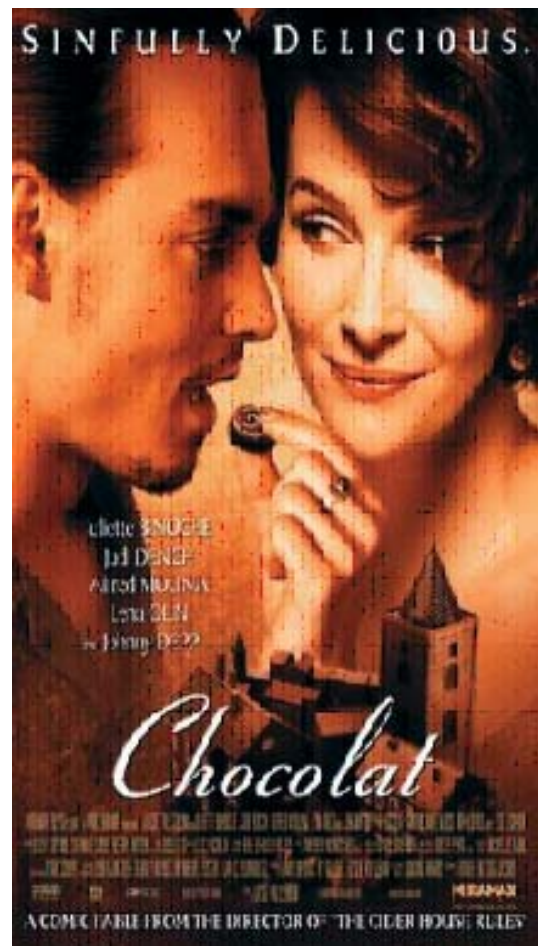

Ciência e mito fundem-se no néctar que, reza a lenda, dava alento e vigor a Montezuma, o último soberano asteca que o consumia em grandes quantidades antes das suas sortidas nocturnas a um bem fornecido harém. Estes rumores auspiciosos alimentaram a mitologia amorosa do chocolatl, a bebida dos deuses, até hoje, ou antes, a comida dos deuses, pelo menos no nome da planta que a fornece, Theobroma cacao como foi baptizada por Lineu.

Foi Montezuma quem introduziu Fernando Cortez às delícias da sua bebida favorita. Segundo William Hickling na sua "History of the Conquest of Mexico» (1838), o conquistador escreveu ao rei Carlos I de Espanha sobre a bebida amarga, uma «bebida divina que aumenta a resistência e combate a fadiga. Uma chávena desta bebida preciosa permite que um homem ande durante um dia inteiro sem comida».

Embora haja muitas dúvidas a quem atribuir o mérito pela divulgação na Europa da bebida divina, é certo que em finais do século XVI pelo menos a nobreza e o clero ibéricos tinham acesso ao chocolate que temperavam com açúcar e especiarias sortidas. 0 primeiro de muitos livros dedicados ao chocolate foi escrito em 1631, o «Curioso tratado de la naturaleza y calidad del chocolate» de Antonio Colmenero de Ledesma, um médico andaluz que não esquece menção às virtudes afrodisíacas da bebida que afirmava ser saudável, tornar corpulentos, afáveis e mais belos os seus apreciadores e fertéis as mulheres que a bebessem.

Os médicos da época devotaram-se a fazer esquecer esta aura proibida com sabor a pecado - embora permanecessem divididos no que respeita ao temperamento do grão e não acertassem nos humores da bebida. De facto, o chocolate tinha toda a aprovação da classe médica que considerava a bebida quasi uma panaceia. Foram famílias quaker na Inglaterra do século XIX que deram uma contribuição preciosa para a sua democratização e acessibilidade na forma de barras. Os Cadburys, Terrys, Rowntrees e Frys acreditavam que o chocolate poderia ser uma arma poderosa no movimento que pretendia moderação no consumo ou mesmo abstinência total de bebidas intoxicantes - e que culminou na famosa Lei Seca nos Estados Unidos. Nas suas lojas forneciam chocolate (e café e chá) às classes trabaIhadoras britânicas como alternativa ao álcool que consideravam culpado pelas condições miseráveis de vida em que estas viviam.

Mas será que há algo que justifique todo o imaginário que rodeia o chocolate? A resposta, afirmativa, encontrase na (boa) química do chocolate. A semente de cacau contém mais de 400 compostos, alguns dos quais antioxidantes já nossos conhecidos, polifenóis como o ácido gálico e a epicatequina que combatem os radicais livres. Contém ainda compostos como o triptofano e a teobromina, um alcalóide da família das metilxantinas a que pertence também a cafeína, substâncias estimulantes e desencadeadoras de sensações de prazer.

No chocolate encontramos ainda feniletilamina, um químico que se concentra em pessoas apaixonadas e daí a sensação de felicidade que sentimos quando um pedaço de chocolate se derrete na boca. Mas a existência de chocólatras talvez seja justificada por uma série de compostos detectados no chocolate há apenas 12 anos, canabinóides muito semelhantes à anandamida e $\mathrm{N}$-aciletanolamidas que inibem a degradação da anandamida.

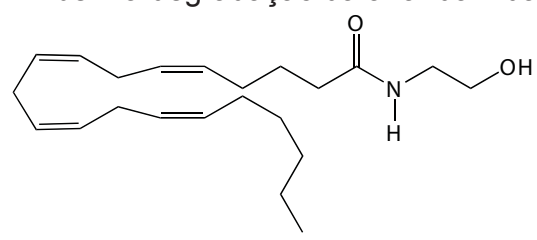

Anandamida

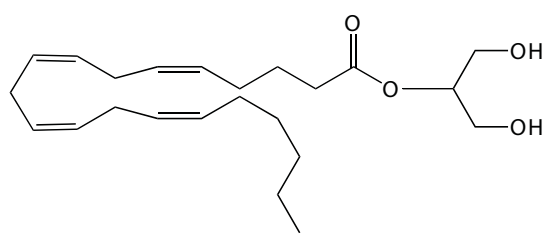

2-glicerol araquidonil 
A anandamida, que deve o nome ao termo sânscrito que significa prazer ou felicidade suprema, ananda, foi a primeira molécula a ser descoberta (em 1992 na Universidade de Jerusalém) que respondeu à pergunta que intrigava a comunidade científica desde a década de 80 do século $\mathrm{XX}$, altura em que foram descobertos os receptores canabinóides, CB1 e CB2, considerados os responsáveis por muitos efeitos bioquímicos e farmacológicos produzidos por canabinóides exógenos como os encontrados na marijuana ou haxixe. Era quase inconcebível para a maioria dos neurologistas que o cérebro animal fosse gastar energia e recursos simplesmente para produzir um receptor para uma substância oriunda de uma planta. Tinha de existir uma molécula natural que se ligasse a estes receptores e, tal como tinha acontecido para os opióides, a descoberta de receptores biológicos para canabinóides exógenos lançou a busca de canabinóides endógenos. A anandamida foi o primeiro endocanabinóide encontrado (e o mais interessante até hoje) mas já se conhecem outros de que se destaca o glicerol araquidonil (2-AG).

A etanolamida do ácido araquidónico ou anandamida é também um agonista do receptor vanilóide VR1. (Os vanilóides são nocireceptores - receptores associados à dor). Dentre os vanilóides naturais exógenos mais conhecidos estão a capsaicina da pimenta, o seu análogo ultrapotente, a resiniferatoxina - isolada da planta Euphorbia resinifera - e a piperina da pimenta do reino, moléculas muito interessantes de per se mas que no contexto do chocolate tornam ainda mais curiosa a escolha de especiarias com que temperavam a oferta dos deuses os antigos maias e astecas.

Fora do cérebro, a anandamida funciona como um mensageiro químico entre o embrião e o útero durante a implantação do embrião na parede uterina. Isto é, a anandamida é uma das nossas formas de comunicação mais primárias.
Estas descobertas químicas no chocolate confirmam as palavras prescientes de Geronimo Piperni que nos idos de 1796 se the referiu nos seguintes termos: "O chocolate é comida celestial, a transpiração das estrelas, a semente vital, néctar divino, bebida dos deuses, panaceia e medicamento universal».

Assim, o chocolate é uma substância estranhamente paradoxal, quimicamente associada ao prazer e à temperança, historicamente ligada ao luxo aristocrata e à democracia, disponível para todos mas no entanto peculiarmente exclusiva. Nesta época do ano em que o chocolate tem um papel proeminente, sigamos pois o conselho de Fernando Pessoa e deleitemo-nos com esta ambrósia para o corpo e elixir para a mente.

\section{A Químıca do Uísque}

Será o uísque a bebida quimicamente mais complicada? Desvendam-se aqui alguns dos segredos do uísque de malte escocês.

Haverá uma razão objectiva para a "libertação de sabores" conseguida por diluição do uísque, por exemplo por adição de água (à temperatura indicada!)? Haverá um modo adequado para fazer essa diluição e uma razão para tal? Não há uma composição química única que descreva um uísque. Não há, por isso, uma maneira única de explicar o que se passa num copo de uísque quando se adiciona água, gelo ou mesmo (que o céu não o permita !) cola.

\section{FABRICANDO SABORES E AROMAS}

O uísque contém centenas de compostos, incluindo ácidos gordos, ésteres, álcoois e aldeídos, numa vasta gama de concentrações. Segundo Paul Hughes, director do International Centre for Brewing and Distilling (ICBD) na Heriot-Watt University em Edimburgo, os sabores e aromas mais importan- tes do uísque provêm das "matérias-primas, do processo de destilação e da maturação". Ou seja, dependem da globalidade do processo de fabrico. Começando pelas matérias-primas, ou seja, 10, 12, 16 ou mais anos antes de se verter um uísque escocês num copo, segundo o Scotch Whisky Act [1], o uísque de malte escocês é feito a partir de $100 \%$ de malte de cevada - grão que foi muito brevemente germinado, libertando as enzimas que convertem amido em açúcar que posteriormente se transformará em álcool.

Os produtores de uísque começam com uma massa de malte e água (segundo o Scotch Whisky Act, as destilarias devem usar água como lhes chega, sem qualquer tipo de tratamento). Pretende-se maximizar a transformação do amido do grão em açúcar, para obter o máximo teor de álcool. A solução de açúcar é retirada da massa e adiciona-se-lhe levedura para fermentar. A fermentação demora cerca de 72 horas. No final a solução alcoólica vai para destilação.

É nesta fase que entram os impressionantes e volumosos alambiques de cobre.

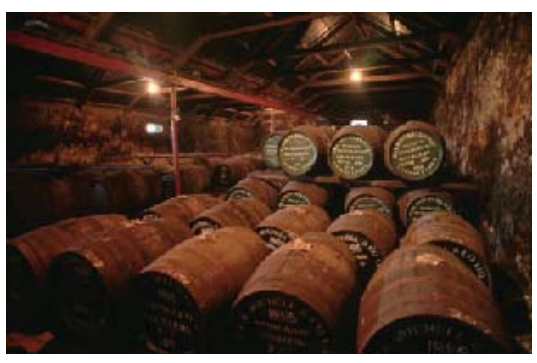

Barris de maturação ou envelhecimento - onde a química decorre durante um período que pode atingir 16 anos

A destilação é essencialmente muito simples: aquece-se a mistura para a separar em fracções de diferentes volatilidades, embora o cobre actue também como catalisador de importantes reacções, como as que removem os compostos sulfurados. Existe uma investigação continuada para garantir que existe uma continuidade do processo de fabrico. Se algo começa a desviar-se, é importante que nas destilarias se identifiquem as causas de forma a repor o processo no seu percurso normal. Na destilação são isoladas três fracções: uma primeira fracção que contém os componentes altamente voláteis (como acetaldeído e acetato de etilo); a fracção do álcool (spirit) que seguirá para ser amadurecida para se obter o Scotch; e a frac- 
ção que contém os compostos de baixa volatilidade, que inclui os fenóis e muitos compostos azotados. A primeira e terceira fracções são recicladas e redestiladas porque contêm álcool.

A maioria do uísque escocês é duplamente destilado, o que constitui uma diferença chave entre os uísques escocês e irlandês. $O$ uísque irlandês é triplamente destilado, o que constitui um aspecto importante na sua comercialização - a pureza. Pode dizer-se que na produção do uísque escocês o objectivo é destilá-lo apenas o suficiente.

\section{A ESPECIARIA DA VIDA}

Há 92 destilarias de malte na Escócia, todas únicas. Cada uma recolhe uma fracção ligeiramente diferente durante a destilação, o que torna os uísques quimicamente diferentes mesmo antes de colocados nos barris para maturação/envelhecimento. Este líquido incolor contém já alguns dos compostos que estarão presentes no sabor final - fenóis, ésteres, lactonas, aldeídos e alguns compostos contendo enxofre e azoto. Mas o barril é o local onde ocorrem de facto as coisas importantes_com o processo de maturação finamente ajustado para cada uísque individual. O tempo de maturação é longo (de 12 a 16 anos) para se obter o equilíbrio correcto. A maioria dos barris são fabricados em carvalho branco Americano e foram já previamente usados no fabrico de bourbon. A indústria Americana de bourbon usa barris novos de cada vez o que, além de os tornar mais baratos para o fabrico de uísque, Ihes confere um pré-tratamento. $\mathrm{O}$ carvalho branco contém muita baunilha que é removida durante o fabrico de bourbon, tornando-os então bons para a maturação do Scotch. Os barris devem ter uma capacidade inferior a 700 litros, dado que a maior parte da química de maturação depende de um bom contacto com a madeira. Ocorrem três tipos de reacções nos barris: aditivas, subtractivas e interactivas. Nas reacções subtractivas, há compostos que se perdem para a madeira, incluindo os sulfurados como o dimetilsulfureto. Além disso ocorre difusão de oxigénio através do barril e ocorrem reacções entre as moléculas da bebida espirituosa e entre esta e a madeira. São oxidados álcoois e aldeídos, e ácidos reagem com etanol para formarem ésteres - os quais constituem a maioria dos compostos aromáticos presentes no uísque. Os barris são muitas vezes queimados no seu interior. A camada de carvão activo que se forma remove alguns dos compostos indesejados e a queima começa a quebra da lenhina da madeira. O etanol reage com a lenhina para a quebrar dando origem a alguns dos compostos que conferem sabor e aroma ao uísque, tais como os aldeídos aromáticos. A queima da madeira dos barris de carvalho promove a produção de lactonas do uísque, compostos que dão aroma e sabor frutado, muitas vezes descritos como dando um cheiro de côco [2]. É a maturação nos barris de madeira que dá ao uísque a cor dourada. O único aditivo permitido, para além da água, é o caramelo, que pode ser adicionado para dar ao uísque uma cor standard.

\section{A IDADE É TUdo}

O Scotch Whisky Act determina que um uísque só é Scotch whisky se tiver sofrido uma maturação de pelo menos três anos, tendo esta que ocorrer na Escócia. Tal determinação está associada ao clima frio e húmido, que afecta a maturação. Nos EUA a concentração de etanol nos barris cresce durante a maturação porque o clima é quente e seco enquanto que na Escócia essa concentração diminui. Após a maturação, um uísque é misturado e diluído para ser engarrafado - o uísque que sai dos barris pode conter mais de $60 \%$ de etanol mas o uísque é engarrafado a $40 \%$. Cada destilaria tem um mestre "misturador" (blender) - uma pessoa capaz de detectar centenas de aromas com o olfacto. Este é ainda um talento que nenhum equipamento analítico pode equiparar. Os uísques de malte single (ou single malt) são habitualmente obtidos misturando o conteúdo de vários barris, todos da mesma destilaria, para obter o sabor e aroma pretendidos. A idade indicada na garrafa corresponde ao mais novo dos uísques da mistura. A crença de que os uísques de malte single são superiores aos uísques de malte de mistura é, por vezes, uma opinião errada. No período de 1890 a 1960 toda a gente bebia uísque de mistura, devido a uma peste que dizimou a maioria dos vinhedos na França e no resto da Europa. No Reino Unido, as pessoas que bebiam brandy não podiam obtê-lo e por isso viraram-se para a Escócia onde se produzia o uísque de malte. Contudo, este era demasiado forte para a maioria das pessoas. Por isso, começaram a produzir uísque de grão - destilado a partir de uma mistura de grãos de cereais, usualmente trigo ou milho, e malte de cevada (cevada que imediatamente após germinação se faz secar) que produz as enzimas necessárias. O uísque de grão é destilado para obter uma maior concentração alcoólica e é suave. Misturando o uísque de grão com o

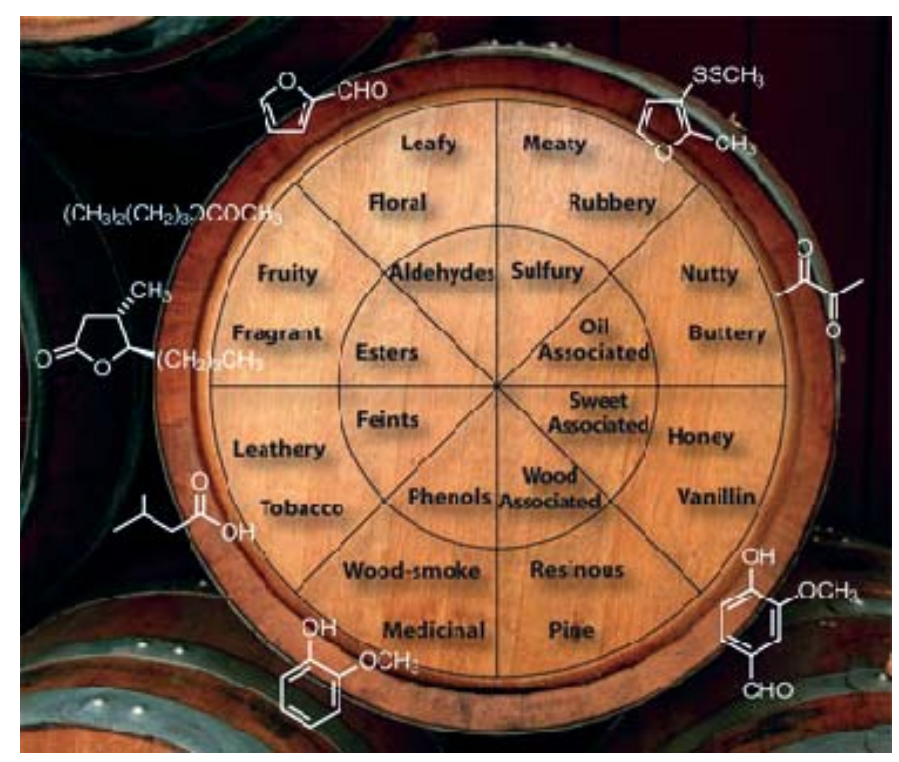

Os provadores de uísque podem usar "rodas de aromas e sabores" para determinar a mistura complexa de compostos que compõem cada uísque 
uísque de malte, obtinha-se uma bebida alcoólica que era aceitável para substituir o brandy como digestivo. Só quando o primeiro uísque de malte single foi comercializado pela Glenfiddich nos anos 1960s é que esta bebida se tornou facilmente acessível, representando cerca de $5 \%$ do mercado de uísque. Num uísque de malte single obtém-se um espectro estreito de sabores e aromas. Um blender pode usar 35 maltes diferentes e dois ou três uísques de grão e misturá-los todos para obter um uísque com todas as características combinadas.

\section{Como beber o vísque}

As formas de consumir o uísque são variadas e complexas. Os puristas do uísque de malte single dizem por vezes que se deve adicionar um pouco de água à temperatura ambiente. Mas, qual a forma correcta de beber o uísque? Quando os blenders cheiram os uísques, estes são previamente diluídos para uma concentração de etanol de $20 \%$ porque usando a concentração de $40 \%$, após alguns ensaios de cheiro, deixa de ser possível identificar os aromas. Como os produtores de uísque dependem muito de equipas de "cheiradores" para efectuarem o controle de qualidade é importante preservar os seus narizes! Com as bebidas espirituosas há uma diluição mágica de $17 \%$ à qual se forma uma fase contínua de água e etanol. Caso contrário, formam-se clusters de etanol nos quais se concentram os compostos solúveis em etanol. Talvez seja necessária uma quantidade adequada de água para obter esta fase contínua. Contudo, com o Scotch a situação é mais complicada porque o uísque não é apenas etanol e água, pelo que é mais complicado estabelecer uma diluição crítica. Foi testada a influência da diluição sobre o impacto sensorial de um uísque[3].

A diluição parece libertar alguns compostos que dão aroma e sabor e mascarar outros.

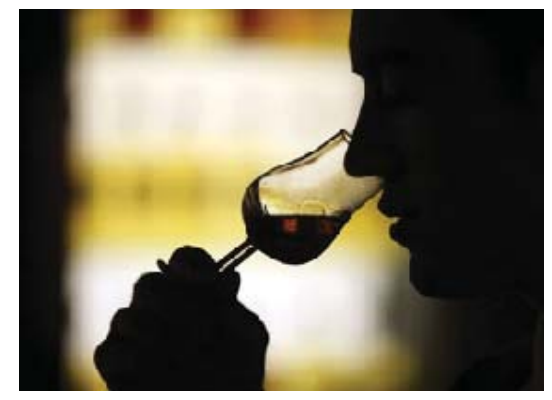

A diluiçãa afecta os aromas dos uísques de maneira diferente

Aumentando o teor de água reduz-se a solubilidade de alguns compostos de cadeia longa, tais como ésteres, e aumenta-se a volatilidade de compostos hidrofóbicos, enquanto se reduz a volatilidade de fenóis e de compostos azotados (associados a aromas e sabores de cereal e de noz tostada). Em conclusão, gostando dos aromas de cereais é preferível beber o uísque puro. A adição de gelo ou de água fria reduz a volatilidade de muitos compostos aromáticos, pelo que se perdem os aromas mas mantém-se o sabor. Um efeito garantido da diluição é a redução da concentração de etanol. Pode ainda reduzir a agrura do uísque. Este efeito é muito pronunciado nos uísques novos, mas é menos pronunciado do que esperado para os uísques envelhecidos. Daqui deriva a ideia de que os uísques de malte bem amadurecidos devem ser bebidos puros. Nas provas de gosto na Scottish Malt Whisky Society os uísques fortalecidos nos barris são diluídos ao gosto. Quando se adiciona água a um uísque ele sabe melhor mas a adição de água a outro pode piorar o sabor (como acontece, por exemplo, com uísques pesados com fortes notas de enxofre - este compostos são libertados quando se dilui o uísque e muitas pessoas acham-no desagradável). Queijo azul e chocolate combinam habitualmente bem com uísque, mas tal depende do gosto pessoal. $\mathrm{Na}$ China é muitas vezes misturado com chá verde. Em Espanha muitas pessoas bebem-no com um aditivo, como a cola. E, segundo uma piada Escocesa bem conhecida, esta é de facto a melhor forma de beber tal coisa: a cola, claro!

\section{REFERÊNCIAS}

[1] The Scotch Whisky Act: www.opsi.gov.uk/ Acts/acts1988/ukpga_19880022_en_1

[2] J. M. Conner, A. Paterson, J. R. Piggott, J. Sci. Food and Agric., 62(2006) 169.

[3] J. M. Conner, A. Paterson, J. R. Piggott, J. Sci. Food and Agric., 79 (1999) 1015.

Texto e figuras adaptados de "A whisky tour", de Victoria Gill, Chemistry World, Dezembro de 2008.

\section{A Química do Chá}

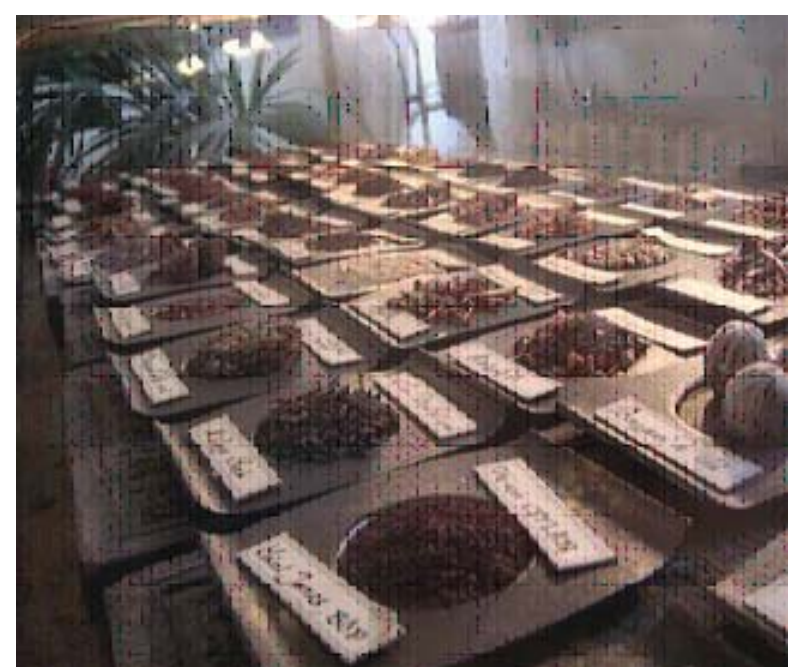

De acordo com a mitologia chinesa, há cerca de 4700 anos, por volta do ano 2737 a.C., o lendário segundo imperador da China, Shen Nong ou Chen-nong, que segundo a lenda teria inventado nada menos que a roda e a charrua, teria igualmente «inventado» a bebida nacional da China num manifestação de serendipidade em tudo semelhante à maçã de Newton.

Conta a lenda que o chá nasceu quando Shen Nong esperava debaixo de uma árvore pela ebulição da água - que reza a lenda o monarca teria igualmente introduzido como forma de prevenir epidemias - e o acaso teria 
causado a queda de duas folhas e um rebento de Camellia sinensis dentro da água fervente.

O aroma que se desprendeu, devido entre outros compostos a metabolitos de carotenóides como teaspirano e iononas, despertou a atenção do monarca que terá assim introduzido um hábito que se tornaria indissociável da cultura chinesa.

Os japoneses - entre os quais se desenvolveu o cha-no-yu, um complexo ritual envolvendo a preparação e consumo desta bebida -, têm igualmente uma lenda que atribui a Boddhidharma a invenção do chá, mas é aceite que o chá foi introduzido no Japão no início do século IX pelo monge Saicho (mais tarde Dengyo Daishi).

Em 804, o imperador Kammu - que tinha transferido a capital de Nara para Heian (Kyoto) devido a lutas de poder entre a aristocracia e a elite clerical budista - enviou para a China duas figuras que, ironicamente, viriam a tornar-se incontornáveis no budismo japonês, Saicho, que para além do chá introduziu o budismo Tendai (ou Tien-t'ai no original chinês) e Kukai que introduziu o budismo Shingon.

As formas diferentes de preparação das folhas de chá, dando origem ao que hoje classificamos como chá verde (e branco), preto e oolong, foram introduzidas na China durante a dinastia Ming (1368-1644 d.C) e basicamente têm a ver com o estágio em que as folhas são processadas com calor.

Depois de colhidas as folhas, inicia-se um processo designado no léxico do quotidiano por fermentação embora o termo seja incorrecto porque com excepção do chá pu-erh não há qualquer micro-organismo envolvido no processo e a dita fermentação do chá é simplesmente a oxidação, mais concretamente a oligomerização oxidativa, de polifenóis existentes no chá.

Os polifenóis constituem um grupo muito diversificado de compostos químicos ubíquos no mundo vegetal e omnipresentes na dieta dos hominídeos ao longo da evolução do homem, que têm merecido a atenção do público em geral nas últimas décadas devido à descoberta das suas propriedades anti-oxidantes - são sequestradores (scavengers) de radicais livres, o que inibe inúmeras doenças mediadas por estas espécies.

Os polifenóis presentes no chá, que representam cerca de $30 \%$ da matéria seca das folhas frescas, incluem flavonóides, flavonas, isoflavonas e ácidos fenólicos, mas são constituidos principalmente por flavonóis (3-hidroxiflavonas ou catequinas), os compostos oxidados durante a "fermentação». O chá e o chocolate são as fontes de catequinas mais importantes da nossa dieta. Nos chás verde e branco o processo de oxidação é inibido com calor (que desactiva as enzimas polifenol oxidases) logo após a colheita e a sua composição é semelhante à encontrada nas folhas acabadas de colher. No chá preto a desactivação térmica da enzima é efectuada após oxidação extensiva dos flavonóis dando origem a dímeros e oligómeros sortidos, como bisflavonóis, teorubígenos (thearubigins) e teoflavinas (theaflavins) que dão conta de aproximadamente $25 \%$ do peso seco do chá preto.

O chá oolong sofre uma oxidação muito curta pelo que este chá apresenta catequinas mono e oligoméricas. As referências ao chá mais antigas na Europa datam do século XVI encontram-se no Delle Navigationi et Viaggi, escrito em 1559 por Giani Battista Ramusio e em textos de frei Gaspar da Cruz, um padre jesuita português, o primeiro ocidental a escrever sobre o chá. Portugal foi igualmente o primeiro país europeu a estabelecer rotas comerciais com a China, por volta de 1515 , e tudo indica que terão sido os padres jesuítas nacionais que evangelizavam nessas terras longínquas os introdutores na Europa do consumo do chá.

Mas Portugal, entretanto sob domínio espanhol, conheceu uma extensão nos seus entrepostos no Oriente da Guerra dos Oitenta Anos. Foram assim os holandeses, dotados de uma poderosa frota no início do século XVII e posteriormente os ingleses que dominaram o comércio do chá. Embora muitos ingleses considerem que o chá foi introduzido em Inglaterra em 1579 por Christopher Borough, o seu consumo só se generalizou após o casamento da infanta Catarina de Bragança com Carlos II de Inglaterra. A futura rainha levava no dote, para além das possessões portuguesas de Bombaim e Tânger, não uma arca de chá como é muitas vezes referido, mas o conhecimento da bebida.

Catarina introduziu várias inovações na corte inglesa, muito provavelmente o hábito do consumo de chá, mas igualmente o uso de baixela de porcelana, comum na corte nacional mas desconhecida em Inglaterra, onde se utilizavam pratos de ouro e prata - as primeiras fábricas de porcelana inglesa foram fundadas em meados do século XVIII, em Chelsea (1743) e Worcester em 1751. As origens do emblemático ritual britânico de consumo de chá em delicadas chávenas de porcelana pode assim ser traçado a Portugal.

PS

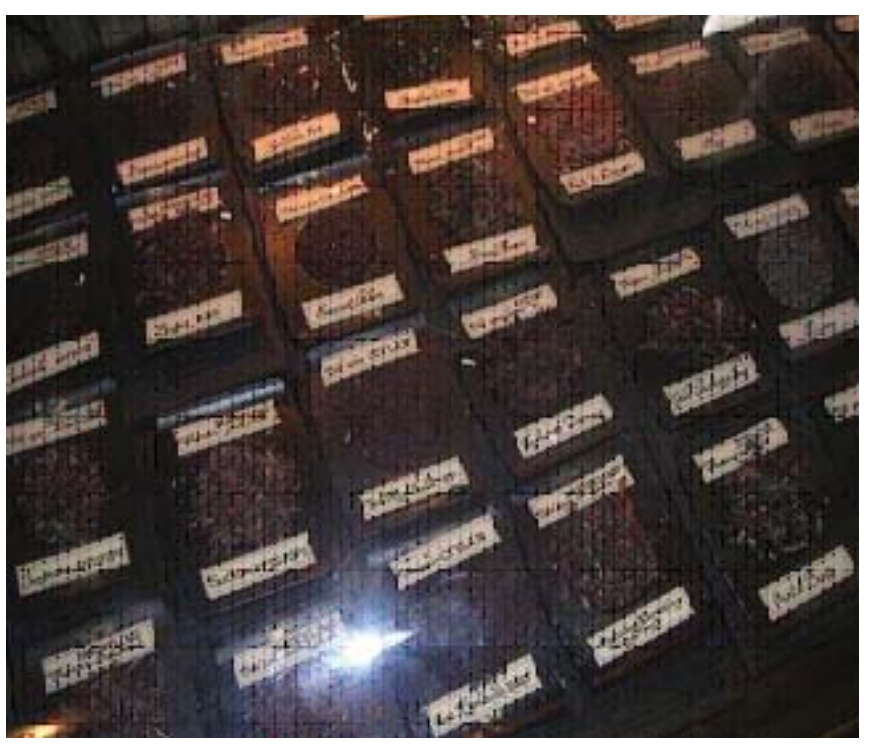

